\title{
Synthesis, in vitro and in vivo antimalarial assessment of sulfide, sulfone and vinyl amide-substituted 1,2,4-trioxanes prepared via thiol-olefin co-oxygenation (TOCO) of allylic alcohols $\uparrow$
}

\author{
Richard Amewu, ${ }^{a}$ Peter Gibbons, ${ }^{a}$ Amira Mukhtar, ${ }^{a}$ Andrew V. Stachulski, ${ }^{a}$ Stephen A. Ward, ${ }^{b}$ Charlotte Hall, ${ }^{b}$ \\ Karen Rimmer, ${ }^{b}$ Jill Davies, ${ }^{b}$ Livia Vivas, ${ }^{d}$ John Bacsa, ${ }^{a}$ Amy E. Mercer, ${ }^{c}$ Gemma Nixon, ${ }^{b}$ Paul A. Stocks ${ }^{b}$ and \\ Paul M. O’Neill $* a$
}

Received 19th November 2009, Accepted 4th February 2010

First published as an Advance Article on the web 3rd March 2010

DOI: 10.1039/b924319d

\begin{abstract}
Thiol-Olefin Co-Oxygenation (TOCO) methodology has been applied to the synthesis of a small library of weak base and polar 1,2,4-trioxanes. The 1,2,4-trioxane units synthesised exhibit remarkable stability as they survive base catalysed hydrolysis and mixed anhydride/amine coupling reactions. This unique stability feature has enabled a range of novel substitution patterns to be incorporated within the spiro 1,2,4-trioxane unit. Selected analogues express potent in vitro $\mathrm{nM}$ antimalarial activity, low cytotoxicity and oral activity in the Plasmodium berghei mouse model of malaria.
\end{abstract}

\section{Introduction}

Malaria is one of the world's most prevalent infectious diseases, remaining a major health problem and, therefore, a developmental barrier for many countries. It is estimated that about $40 \%$ of the world's population is at risk of contracting malaria, leading to around 350-500 million infections coupled with a staggering million deaths per annum. The widely affordable antimalarial drugs such as chloroquine ${ }^{1}$ (1) and sulfadoxine (2), ${ }^{2}$ either as monotherapies or in combination, are now largely ineffective due to drug resistance.

The potential impact of artemisinin (3), a Chinese herbal extract, on malaria chemotherapy is hampered by supply and cost; the majority of infected people needing treatment for malaria cannot afford drugs containing an artemisinin derivative. ${ }^{3}$ Nevertheless, artemisinin and its derivatives remain the most effective antimalarials and are currently used in combination with other drugs recommended by the World Health Organization. ${ }^{4}$

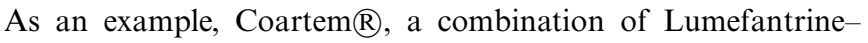
Artemether (Novartis), has been registered and is currently used for the treatment of uncomplicated malaria. ${ }^{5}$

${ }^{a}$ Department of Chemistry, University of Liverpool, P.O. Box 147, Liverpool, UK L693BX. E-mail: P.M.oneill01@liv.ac.uk; Fax: (+44) 1517943588 Tel: (+44) 1517943553

${ }^{b}$ Liverpool School of Tropical Medicine, Pembroke Place, Liverpool, UK L3 5QA

'MRC Centre for Drug Safety Science, Dept of Pharmacology and Therapeutics, The University of Liverpool Sherrington Buildings, Ashton Street, L69 3GE

${ }^{d}$ Department of Infectious and Tropical Diseases, London School of Hygiene and Tropical Medicine, London, UK WC1E 7HT

$\dagger$ Electronic supplementary information (ESI) available: Spectroscopic and analytical data for compounds 16-30 (sulfide trioxanes), 32-42 (trioxane sulfones), 50-54 (trioxane carbaldehydes), 64-65 (trioxane acrylamides), 67-73 (trioxane acrylic acid methyl esters), 75-76 (trioxane acrylic acids) and 79-85 (trioxane amides). CCDC reference numbers 680267, 680268. For ESI and crystallographic data in CIF or other electronic format see DOI: $10.1039 / b 924319 d$

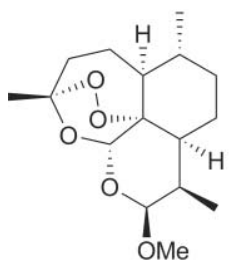

Artemether

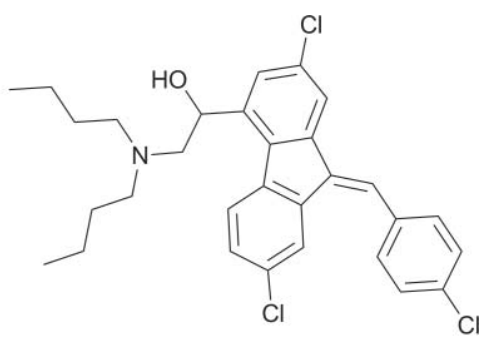

Lumefantrine
Coartem components $=(1: 6$ artemether to lumefantrine $)$

Although the actual mechanism of action of artemisinin and related compounds remains a topic of intense debate, ${ }^{6}$ SAR studies have revealed that the 1,2,4-trioxane heterocycle is the key pharmacophore. ${ }^{7}$ In line with this, various groups have designed and synthesized a variety of compounds containing this functional group, some of which show promising activity towards the malaria parasite. Several methodologies have been developed for the synthesis of the 1,2,4-trioxane pharmocophore, and many of these involve the preparation of an $\alpha$-peroxy alcohol followed by in situ reaction with a carbonyl component in the presence of an acid catalyst. ${ }^{7-10}$ Other approaches include synthesis from nitriles, ${ }^{11}$ reaction of dioxetanes with carbonyls in the presence of Lewis acids, ${ }^{12}$ acid-catalyzed cyclization of hydroxyperoxyacetals with olefins ${ }^{13}$ and reactions of $\alpha$-peroxy aldehydes with carbonyl compounds. $^{14}$

An alternative method for preparing 1,2,4-trioxanes involves the free-radical sequential thiol-olefin co-oxygenation (TOCO) reaction. TOCO chemistry is particularly attractive because it allows functional group manipulation at various stages. In terms of versatility, there are no available methods in the literature for the preparation of sulfide- or sulfone-functionalised spiro 1,2,4trioxanes in just two synthetic steps from readily available building blocks. Furthermore, this chemistry enables rapid access to 1,2,4trioxane aldehydes in only three synthetic steps; such targets are not accessible by alternative published synthetic methodologies. 
<smiles>CCN(C)CCCC(C)Nc1ccnc2cc(Cl)ccc12</smiles>

Chloroquine (1)

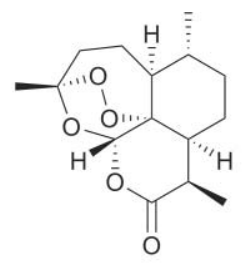

Artemisinin (3)

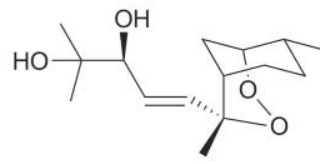

Yinghaosu (4)
TOCO chemistry has been used by various groups ${ }^{15-19}$ for the synthesis of a wide range of cyclic peroxides, including Yingzhaosu $A$ (4), a potent series of bicyclic yingzhaosu A analogues and a series of endoperoxide chalcone pro-drugs. ${ }^{20}$ The reactions are usually initiated by AIBN and ultra violet (UV) irradiation or by di-tert-butylperoxalate (DBPO). We and others have previously used the TOCO methodology to prepare endoperoxides from terpene derivatives (Scheme 1A). ${ }^{18}$ Replacement of the terpene with an allylic alcohol (7 and 8) led to the synthesis of 1,2,4trioxane derivatives (Scheme 1B). ${ }^{19}$ By using the corresponding homo-allylic alcohol analogue of 7, 1,2,4-trioxepanes can also be readily prepared. ${ }^{21}$

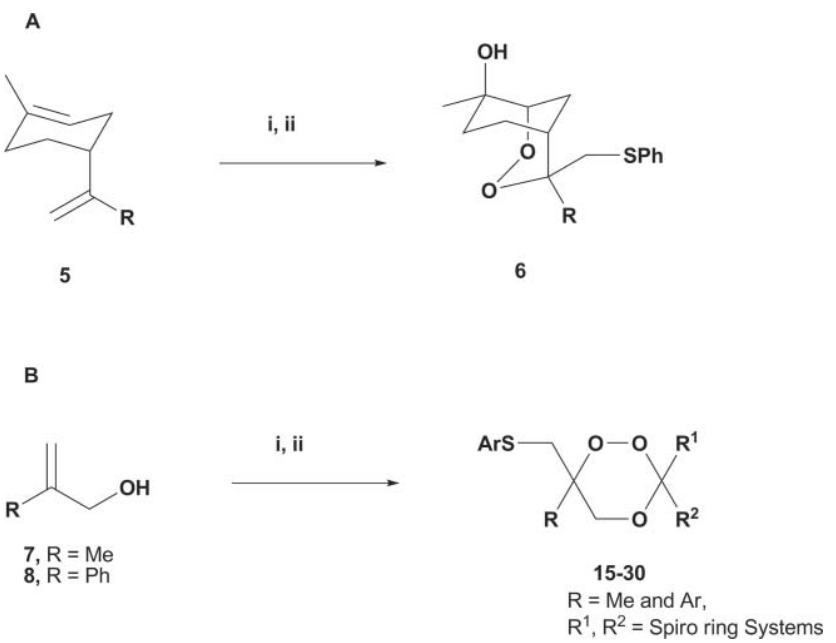

Scheme 1 A) (i) AIBN, ArSH, $\mathrm{O}_{2}, \mathrm{~h} v$. (ii) $\mathrm{PPh}_{3}, \mathrm{CH}_{2} \mathrm{Cl}_{2}, 0-5^{\circ} \mathrm{C}, 2 \mathrm{~h}$ then r.t. 1 h. B) (i) $\mathrm{AIBN}, \mathrm{ArSH}, \mathrm{CH}_{3} \mathrm{CN}, \mathrm{O}_{2}, 0^{\circ} \mathrm{C}, 4-6 \mathrm{~h}$ (ii) $\mathrm{R}^{1} \mathrm{R}^{2} \mathrm{C}=\mathrm{O}$, TsOH, $\mathrm{CH}_{2} \mathrm{Cl}_{2}$, r.t.

We report herein the application of the thiol-olefin cooxygenation to the synthesis of a library of novel 1,2,4-trioxane analogues. Subsequent conversion of the newly incorporated sulfide functional group into more polar functional groups has been performed in a systematic fashion to reduce the $\mathrm{Clog} P$ and improve the aqueous solubility profiles of hit molecules (vide infra).

\section{Results and discussion}

With AIBN as a radical initiator and UV irradiation, we performed a one-pot reaction of the allylic alcohol (7 or 8) and 4chlorothiophenol in acetonitrile. In this process, a thiyl radical is generated which subsequently adds onto the double bond of the allylic alcohol in a Markovnikov fashion to form a tertiary carbon-centred radical 9 . The carbon-centered radical then reacts with molecular oxygen to form a peroxy radical 11. Abstraction of hydrogen by $\mathbf{1 1}$ from the 4-chlorothiophenol species produces a racemic mixture of $\alpha$-hydroperoxyl intermediate $\mathbf{1 3}$ and liberates a second thiyl radical to propagate the reaction (Scheme 2). It was anticipated that stabilizing the carbon-centred radical could improve the reaction; hence the commercially available 2-methyl-2propen-1-ol (7) was replaced with 2-phenyl-2-propen-1-ol (8). The reaction of the allylic alcohol $\mathbf{8}$ occurs via the same mechanism to produce the peroxy radical $\mathbf{1 2}$ and a racemic mixture of the hydroperoxy intermediate $\mathbf{1 4}$. Intermediate $\mathbf{1 4}$ undergoes smooth condensation with a wide range of ketones in the presence of tosic acid catalyst to afford the 1,2,4-trioxanes 15-30 (Table 1) in good yields.
$\mathrm{ArSH}$<smiles>C=C(C)CO</smiles>

7, $\mathrm{R}=\mathrm{Me}$ 8, $\mathrm{R}=\mathrm{Ph}$ $\mathrm{Ar}=p$-Chlorophenyl or Phenyl $\mathrm{R}^{1}$ and $\mathrm{R}^{2}=\left(\mathrm{CH}_{2}\right)_{4},\left(\mathrm{CH}_{2}\right)_{5}$, $\left(\mathrm{CH}_{2}\right)_{11}$ and adamantylidene etc.
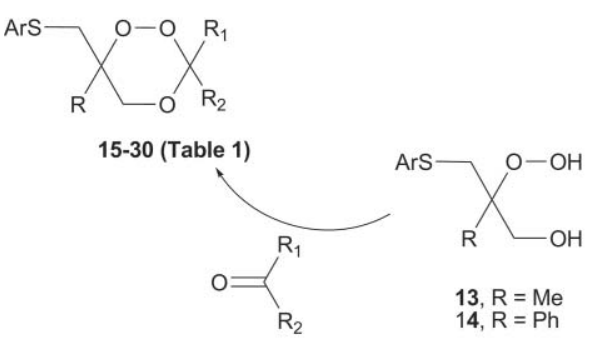

$\mathrm{TsOH}$ (cat) 13, $R=M e$
$14, R=P h$

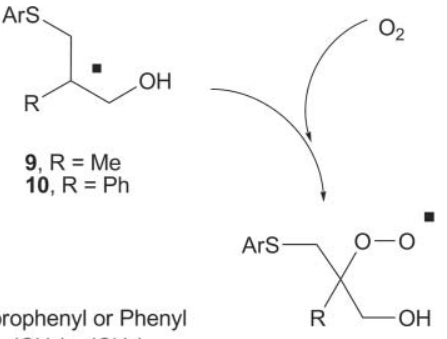

11, $\mathrm{R}=\mathrm{Me}$
$12 \mathrm{R}=\mathrm{Ph}$

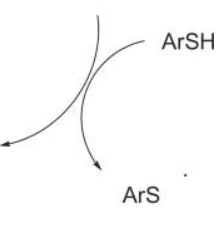

Scheme 2

Replacement of the allylic alcohol 7 with 8 had marginal effect on the yield but purification was much easier. Considering the multi-step nature of the reaction, and the sequence of events leading to the formation of several new bonds, the TOCO reactions proceed in very good yield.

Room temperature ${ }^{1} \mathrm{H}$ NMR analysis of the sulfides 15-30 revealed the $\mathrm{OCH}_{2}$ and $\mathrm{SCH}_{2}$ protons as broad singlets. This results from interconversion of different conformations due to ring flipping of the six-membered trioxane ring system. The peaks were resolved into two doublets (d) for $\mathbf{1 5}$ and $\mathbf{1 8}$ by performing variable temperature analysis. While $\mathbf{1 8}$ was resolved at $0{ }^{\circ} \mathrm{C} ; 3.49$ $\left(\mathrm{d}, 1 \mathrm{H}, J=13.1 \mathrm{~Hz}, \mathrm{SCH}_{2}\right), 3.61\left(\mathrm{~d}, 1 \mathrm{H}, J=13.1 \mathrm{~Hz}, \mathrm{SCH}_{2}\right), 3.68$ $\left(\mathrm{d}, 1 \mathrm{H}, J=12.0 \mathrm{~Hz}, \mathrm{OCH}_{2}\right), 3.82\left(\mathrm{~d}, 1 \mathrm{H}, J=12.0 \mathrm{~Hz}, \mathrm{OCH}_{2}\right.$ ), 
Table 1 Trioxanes synthesized via the TOCO reaction with cyclic ketones

\begin{tabular}{|c|c|c|c|}
\hline 15 & $\left(\mathrm{CH}_{2}\right)_{5}$ & $\mathbf{R}^{3}=\mathrm{Me} ; \mathbf{R}^{4}=p$-Cl-Ph-S- & 64 \\
\hline 16 & $\left(\mathrm{CH}_{2}\right)_{4}$ & $\mathbf{R}^{3}=\mathrm{Me} ; \mathbf{R}^{4}=p-\mathrm{Cl}-\mathrm{Ph}-\mathrm{S}-$ & 78 \\
\hline 20 & $\left(\mathrm{CH}_{2}\right)_{11}$ & $\mathbf{R}^{3}=\mathrm{Ph} ; \mathbf{R}^{4}=p$-Cl-Ph-S- & 46 \\
\hline 21 & $\left(\mathrm{CH}_{2}\right)_{5}$ & $\mathbf{R}^{3}=\mathrm{Ph} ; \mathbf{R}^{4}=\mathrm{Ph}-\mathrm{S}-$ & 68 \\
\hline 22 & $\left(\mathrm{CH}_{2}\right)_{4}$ & $\mathbf{R}^{3}=\mathrm{Ph} ; \mathbf{R}^{4}=\mathrm{Ph}-\mathrm{S}-$ & 54 \\
\hline 23 & $\left(\mathrm{CH}_{2}\right)_{5}$ & $\mathbf{R}^{3}=\mathrm{Me} ; \mathbf{R}^{4}=\mathrm{Ph}-\mathrm{S}-$ & 53 \\
\hline 24 & $\left(\mathrm{CH}_{2}\right)_{3}$ & $\mathbf{R}^{3}=\mathrm{Me} ; \mathbf{R}^{4}=\mathrm{Ph}-\mathrm{S}-$ & 61 \\
\hline 25 & Adamantylidene & $\mathbf{R}^{3}=\mathrm{Me} ; \mathbf{R}^{4}=\mathrm{Ph}-\mathrm{S}-$ & 42 \\
\hline
\end{tabular}

15 required further cooling to $-20{ }^{\circ} \mathrm{C} ; 3.48(\mathrm{~d}, 1 \mathrm{H}, J=13.1 \mathrm{~Hz}$, $\left.\mathrm{SCH}_{2}\right), 3.62\left(\mathrm{~d}, 1 \mathrm{H}, J=13.1 \mathrm{~Hz}, \mathrm{SCH}_{2}\right), 3.69(\mathrm{~d}, 1 \mathrm{H}, J=12.1 \mathrm{~Hz}$, $\left.\mathrm{OCH}_{2}\right), 3.88\left(\mathrm{~d}, 1 \mathrm{H}, J=12.1 \mathrm{~Hz}, \mathrm{OCH}_{2}\right)$. This suggests that the cut off temperature at which the flipping begins is governed by the nature of the groups attached to the ring.

Posner and co-workers observed that within a series of tricyclic 1,2,4-trioxanes, the sulfone group imparted high antimalarial potency even in instances where the corresponding sulfide displayed no activity. ${ }^{22,23}$ Thus, we prepared the sulfones 31-42 from the sulfides 15-30 using 2.2 equivalents of $m \mathrm{CPBA}^{24}$ (Scheme 3, Table 2) in high yields. For compound 35, a single X-ray crystal structure (as dimethyl formamide solvate) was solved and is depicted in Fig. 1.

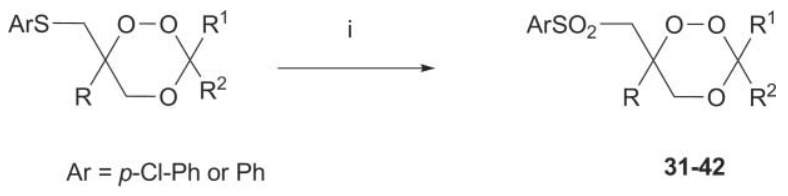

Scheme 3 (i) $m \mathrm{CPBA}$ (2.2 equiv.), $\mathrm{CH}_{2} \mathrm{Cl}_{2}, 4-6$ h, r.t.

A major limitation with many synthetic endoperoxide antimalarials is their poor oral bioavailability which stems in part from limited aqueous solubility. Our next focus was to make
Table 2 Trioxanes sulfones synthesized

\begin{tabular}{|c|c|c|c|c|}
\hline Compound & $R$ & $\mathrm{R}^{1}$ and $\mathrm{R}^{2}$ & $\mathrm{Ar}$ & Yield $(\%)$ \\
\hline 31 & $\mathrm{Me}$ & $\left(\mathrm{CH}_{2}\right)_{4}$ & $p-\mathrm{Cl}-\mathrm{Ph}$ & 76 \\
\hline 32 & $\mathrm{Me}$ & $\left(\mathrm{CH}_{2}\right)_{5}$ & $p$-Cl-Ph & 80 \\
\hline 33 & $\mathrm{Me}$ & $\left(\mathrm{CH}_{2}\right)_{11}$ & $p$-Cl-Ph & 80 \\
\hline 34 & $\mathrm{Me}$ & Adamantylidene & $p$-Cl-Ph & 80 \\
\hline 35 & $\mathrm{Ph}$ & $\left(\mathrm{CH}_{2}\right)_{5}$ & $p-\mathrm{Cl}-\mathrm{Ph}$ & 77 \\
\hline 36 & $\mathrm{Ph}$ & $\left(\mathrm{CH}_{2}\right)_{11}$ & $p-\mathrm{Cl}-\mathrm{Ph}$ & 79 \\
\hline 37 & $\mathrm{Me}$ & $\left(\mathrm{CH}_{2}\right)_{5}$ & $\mathrm{Ph}$ & 75 \\
\hline 38 & $\mathrm{Me}$ & $\left(\mathrm{CH}_{2}\right)_{3}$ & $\mathrm{Ph}$ & 91 \\
\hline 39 & $\mathrm{Me}$ & Adamantylidene & $\mathrm{Ph}$ & 56 \\
\hline 40 & $\mathrm{Me}$ & 4-t-Butylcyclohexyl & $p-\mathrm{Cl}-\mathrm{Ph}$ & 92 \\
\hline 41 & $\mathrm{Me}$ & 1,4-Cyclohexanedione & $\mathrm{Ph}$ & 82 \\
\hline 42 & $\mathrm{Me}$ & $\left(\mathrm{CH}_{2}\right)_{11}$ & $\mathrm{Ph}$ & 93 \\
\hline
\end{tabular}

the 1,2,4-trioxanes more polar by incorporation of amide side chains. First, the sulfides 15-20 were oxidised with a stoichiometric amount of $m \mathrm{CPBA}$ to generate the corresponding sulfoxides 43-48 (Scheme 4). Secondly, 43-48 were exposed to Pummerer conditions according to the method reported by Arroyo-Gomez and co-workers ${ }^{25,26}$ to give the aldehydes 49-54 in high yield.

Manipulation of the resulting aldehydes led to mixed results; oxidation of aldehyde $\mathbf{5 2}^{\mathbf{2 7} 28}$ to the corresponding carboxylic acid $\mathbf{5 5}$ failed, as did reductive amination ${ }^{29,30}$ with morpholine ((Scheme 5) to give amine 57). For substrates 49-54, it appears
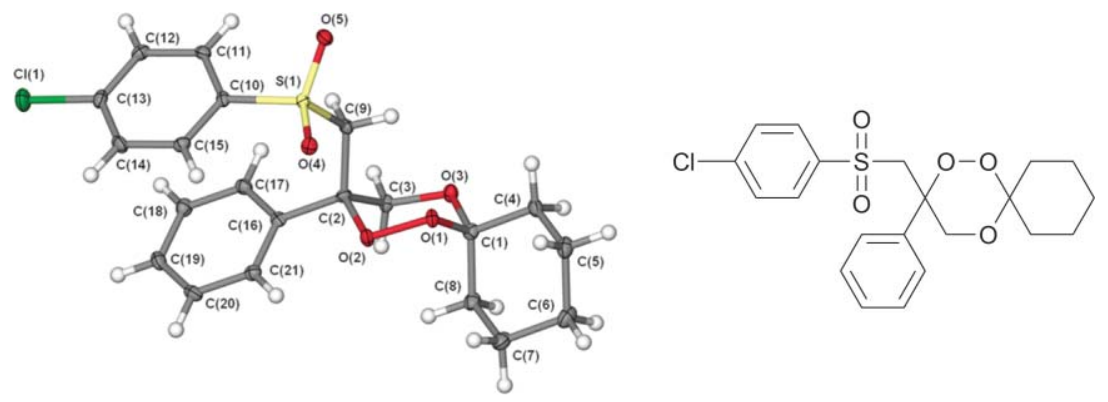

Fig. 1 Single-crystal X-ray structure of the trioxane sulfone 35 (CCDC 680267). Non-H atoms are represented by thermal ellipsoids at the 50\% probability level and $\mathrm{H}$-atoms are shown as circles with arbitrary radii. 


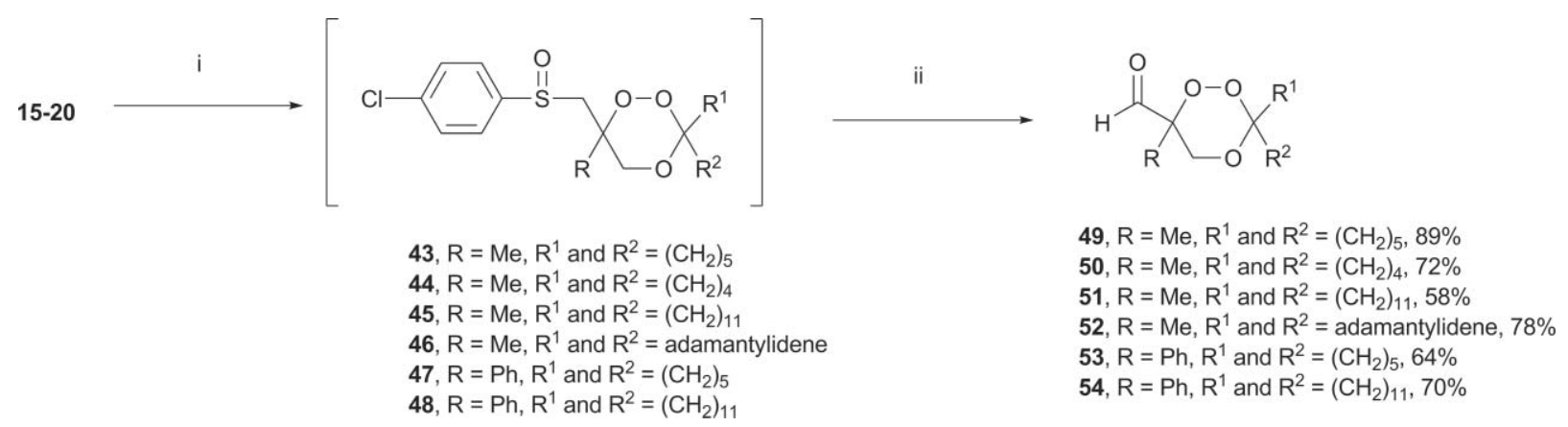

Scheme 4 (i) $m \mathrm{CPBA}$ (1 equiv.), $\mathrm{CH}_{2} \mathrm{Cl}_{2}, 4-6$ h, r.t., (ii) TFAA, $\mathrm{CH}_{2} \mathrm{Cl}_{2}, 2$,6-lutidine, 3 h, r.t.

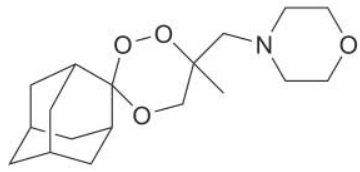

57

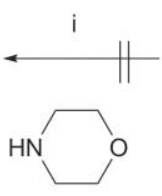

56

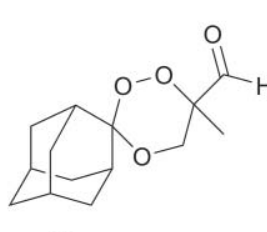

52

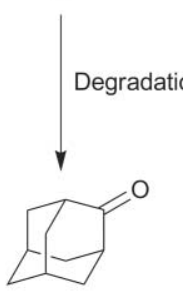

58

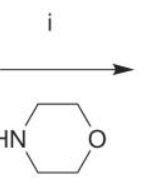

56

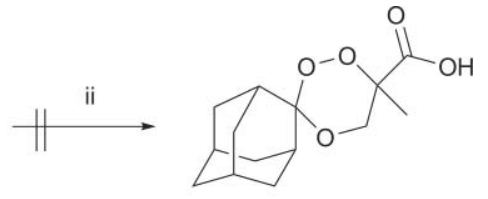

55

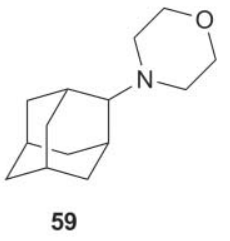

59

Scheme 5 (i) $\mathrm{NaBH}(\mathrm{OAc})_{3}, \mathrm{CH}_{2} \mathrm{Cl}_{2}, 18$ h, r.t. (ii) ${ }^{t} \mathrm{BuOH}, \mathrm{H}_{2} \mathrm{O}, 2$-methylbutene, $\mathrm{NaH}_{2} \mathrm{PO}_{4}, \mathrm{NaClO}_{2}, 2$ h, r.t.

that the close proximity of the aldehyde to the endoperoxide bridge results in decomposition in the presence of tertiary butoxide $\left({ }^{t}-\mathrm{BuO}^{-}\right)$or cyclic amines.

While the oxidation led to a complex mixture of products, none of which were the desired carboxylic acid $\mathbf{5 5}$, the reductive amination reaction led to the formation of $\mathbf{5 9}$ (via reductive amination of 58), presumably generated from the breakdown of 52. A series of vinyl-substituted trioxanes 60-73 was prepared from the aldehydes 49-54 via Wittig reactions (Scheme 6) ${ }^{31}$ with various ylides in very good yield, with the exception of $\mathrm{Ph}_{3} \mathrm{P}=\mathrm{CHCON}\left(\mathrm{C}_{2} \mathrm{H}_{5}\right)_{2}$. $\left(\mathrm{Ph}_{3} \mathrm{P}=\mathrm{CHCON}\left(\mathrm{C}_{2} \mathrm{H}_{5}\right)_{2}\right.$ was prepared by refluxing $N, N$-diethylchloroacetamide with triphenylphosphine in nitromethane. ${ }^{32}$

Reaction of a range of aldehydes with the methyl and ethyl ester Wittig reagent gave 66-73 predominantly as trans-geometric isomers $(J>15 \mathrm{~Hz})$. However, in contrast, the reaction with $\mathrm{Ph}_{3} \mathrm{P}=\mathrm{CHCON}\left(\mathrm{C}_{2} \mathrm{H}_{5}\right)_{2}$ resulted in 63-65 as a mixture of geometric isomers with the trans-isomer being the major product. The ratio of the trans: cis, determined from the fraction of major and minor isolated products, is $9: 1,4: 1,4: 1$ for $\mathbf{6 3}, \mathbf{6 4}$ and $\mathbf{6 5}$, respectively. The cis- and trans-geometric isomers were assigned based on the coupling constants of the vinyl protons $(J \sim 13$ and $16 \mathrm{~Hz}$, respectively). Broadening of proton signals observed with the $\mathrm{OCH}_{2}$ and $\mathrm{CH}_{2} \mathrm{~S}$ of 15-30 was encountered with the vinyl protons of the amides 63-65. The broadening was resolved by running the ${ }^{1} \mathrm{H}$ NMR at $-20{ }^{\circ} \mathrm{C}$. For example, the vinyl protons for $\mathbf{6 5}$ gave their chemical shifts as $6.66(\mathrm{~d}, 1 \mathrm{H}, J=15.4 \mathrm{~Hz}, \mathrm{CH})$ and $6.89(\mathrm{~d}, 1 \mathrm{H}, J=15.4 \mathrm{~Hz}, \mathrm{CH})$ for the major fraction, and $5.52(\mathrm{~d}, 1 \mathrm{H}, J=13.1 \mathrm{~Hz}, \mathrm{CH})$ and $6.07(\mathrm{~d}, 1 \mathrm{H}, J=13.1 \mathrm{~Hz}, \mathrm{CH})$ for the minor fraction.

The molecules 60, 61 and $\mathbf{6 2}$ have the capacity to release chalcone derivatives, while analogues 63-73 can release fumaratelike structures following reductive cleavage of the endoperoxide bridge with $\mathrm{Fe}(\mathrm{II})$. Part of our future investigations will focus on the mechanistic studies of the iron-mediated degradation chemistry of this class of compounds.

Further manipulation of the ester functionality of 63-73 was also attempted. The most important observation was that the vinyl esters readily undergo base-catalysed hydrolysis to the corresponding carboxylic acids (Scheme 7). ${ }^{33,34}$ The reactions were surprisingly successful despite the use of potassium hydroxide $(\mathrm{KOH})$ at high temperatures indicating the remarkable stability of the 1,2,4-trioxane within this series of trioxanes.

Opsenica and co-workers observed that inclusion of an amide moiety as an auxiliary functional group increases their antimalarial activity. ${ }^{35}$ This observation was made during their work exploring the influence of steroid carriers on the antimalarial and antiproliferative activity of cholic acid-derived tetraoxanes. Our recent work on 1,2,4,5-tetraoxanes also demonstrated that the presence of an amide bond and basic amine side-chains significantly improves antimalarial activity and disposition by enhancing aqueous solubility. ${ }^{36}$ Based on this principle, a series 
<smiles>[R]C1(/C=C\[Al])COC([R])(/C=C\[Al])OO1</smiles>

60, $\mathrm{R}=\mathrm{Ph}, \mathrm{R}^{1}$ and $\mathrm{R}^{2}=\left(\mathrm{CH}_{2}\right)_{11}, \mathrm{Ar}=\mathrm{Ph}, 69 \%$

61, $R=M e, R^{1}$ and $R^{2}=$ adamantylidene, $\mathrm{Ar}=\mathrm{Ph}, 62 \%$

62, $\mathrm{R}=\mathrm{Ph}, \mathrm{R}^{1}$ and $\mathrm{R}^{2}=\left(\mathrm{CH}_{2}\right)_{5}, \mathrm{Ar}=\mathrm{Ph}, 74 \%$

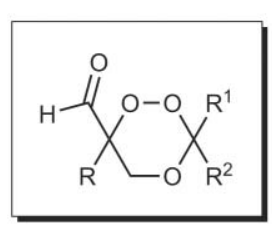

ii<smiles>[R]C1([R])COC([R])(/C=C/C(=O)N(CC)CC)OCO1</smiles>

63, $\mathrm{R}=\mathrm{Me}, \mathrm{R}^{1}$ and $\mathrm{R}^{2}=\left(\mathrm{CH}_{2}\right)_{5}, 45 \%$

64, $R=M e, R^{1}$ and $R^{2}=\left(\mathrm{CH}_{2}\right)_{4}, 43 \%$

65, $R=M e, R^{1}$ and $R^{2}=$ adamantylidene, $47 \%$<smiles>[R20]C(=O)/C=C(/C)C1COC([R])([R])OO1</smiles>

66, $\mathrm{R}=\mathrm{Me}, \mathrm{R}^{1}$ and $\mathrm{R}^{2}=\left(\mathrm{CH}_{2}\right)_{4}, \mathrm{R}^{3}=\mathrm{CH}_{3}, 62 \%$

67, $R=M e, R^{1}$ and $R^{2}=\left(\mathrm{CH}_{2}\right)_{5}, \mathrm{R}^{3}=\mathrm{CH}_{3}, 61 \%$

68, $R=M e, R^{1}$ and $R^{2}=$ adamantylidene, $R^{3}=\mathrm{CH}_{3}, 72 \%$

69, $\mathrm{R}=\mathrm{Me}, \mathrm{R}^{1}$ and $\mathrm{R}^{2}=\left(\mathrm{CH}_{2}\right)_{4}, \mathrm{R}^{3}=\mathrm{C}_{2} \mathrm{H}_{5}, 78 \%$

70, $\mathrm{R}=\mathrm{Me}, \mathrm{R}^{1}$ and $\mathrm{R}^{2}=\left(\mathrm{CH}_{2}\right)_{5}, \mathrm{R}^{3}=\mathrm{C}_{2} \mathrm{H}_{5}, 66 \%$

$71, R=M e, R^{1}$ and $R^{2}=$ adamantylidene, $R^{3}=C_{2} H_{5}, 89 \%$

72, $\mathrm{R}=\mathrm{Ph}, \mathrm{R}^{1}$ and $\mathrm{R}^{2}=\left(\mathrm{CH}_{2}\right)_{5}, \mathrm{R}^{3}=\mathrm{C}_{2} \mathrm{H}_{5}, 59 \%$

$73, \mathrm{R}=\mathrm{Ph}, \mathrm{R}^{1}$ and $\mathrm{R}^{2}=\left(\mathrm{CH}_{2}\right)_{11}, \mathrm{R}^{3}=\mathrm{C}_{2} \mathrm{H}_{5}, 44 \%$

Scheme 6 (i) $\mathrm{ArCH}={ }^{+} \mathrm{P}(\mathrm{Ph})_{3} \mathrm{Br}^{-}$, NHMDS, THF, 75 min, r.t. (ii) $\mathrm{Ph}_{3} \mathrm{P}^{+} \mathrm{CH}_{2} \mathrm{CON}\left(\mathrm{C}_{2} \mathrm{H}_{5}\right)_{2} \mathrm{Br}^{-}, \mathrm{CHCl}_{3}, \mathrm{H}_{2} \mathrm{O}, \mathrm{NaOH}$, r.t., 1 h. (iii) $\mathrm{Ph}_{3} \mathrm{P}=\mathrm{CHCOR}$, $\mathrm{CH}_{2} \mathrm{Cl}_{2}, 3$ h, r.t.<smiles>[R]C1(/C=C/C(=O)OC(=O)OCC)COC([R])([R])C([R])(C=CC(=O)O)O1</smiles>

$66-73$

74, $\mathrm{R}=\mathrm{Me}, \mathrm{R}^{1}$ and $\mathrm{R}^{2}=\left(\mathrm{CH}_{2}\right)_{4}, 86 \%$

77

75, $R=\mathrm{Me}, \mathrm{R}^{1}$ and $\mathrm{R}^{2}=$ adamantylidene, $64 \%$

76, $\mathrm{R}=\mathrm{Ph}, \mathrm{R}^{1}$ and $\mathrm{R}^{2}=\left(\mathrm{CH}_{2}\right)_{5}, 84 \%$

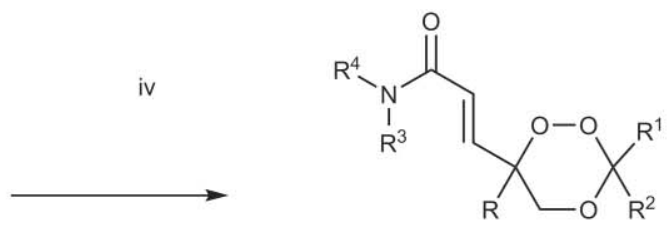

78, $\mathrm{R}=\mathrm{Me}, \mathrm{R}^{1}$ and $\mathrm{R}^{2}=\left(\mathrm{CH}_{2}\right)_{4}, \mathrm{R}^{3}$ and $\mathrm{R}^{4}=\left(\mathrm{CH}_{2}\right)_{4} \mathrm{O}, 83 \%$

79, $\mathrm{R}=\mathrm{Me}, \mathrm{R}^{1}$ and $\mathrm{R}^{2}=\left(\mathrm{CH}_{2}\right)_{4}, \mathrm{R}^{3}=\mathrm{H}$, and $\mathrm{R}^{4}=\mathrm{CH}_{2} \mathrm{CH}_{2} \mathrm{~N}\left(\mathrm{CH}_{2}\right)_{4} \mathrm{O}, 81 \%$

80, $\mathrm{R}=\mathrm{Me}, \mathrm{R}^{1}$ and $\mathrm{R}^{2}=\left(\mathrm{CH}_{2}\right)_{4}, \mathrm{R}^{3}=\mathrm{H}$, and $\mathrm{R}^{4}=\mathrm{CH}_{2} \mathrm{CH}_{2} \mathrm{~N}\left(\mathrm{C}_{2} \mathrm{H}_{5}\right)_{2}, 77 \%$

$\mathbf{8 1}, \mathrm{R}=\mathrm{Me}, \mathrm{R}^{1}$ and $\mathrm{R}^{2}=$ adamantylidene, $\mathrm{R}^{3}$ and $\mathrm{R}^{4}=\left(\mathrm{CH}_{2}\right)_{4} \mathrm{O}, 80 \%$

82, $\mathrm{R}=\mathrm{Me}, \mathrm{R}^{1}$ and $\mathrm{R}^{2}=$ adamantylidene, $\mathrm{R}^{3}=\mathrm{H}$, and $\mathrm{R}^{4}=\mathrm{CH}_{2} \mathrm{CH}_{2} \mathrm{~N}\left(\mathrm{CH}_{2}\right)_{4} \mathrm{O}, 78 \%$

83, $\mathrm{R}=\mathrm{Me}, \mathrm{R}^{1}$ and $\mathrm{R}^{2}=$ adamantylidene, $\mathrm{R}^{3}=\mathrm{H}$, and $\mathrm{R}^{4}=\mathrm{CH}_{2} \mathrm{CH}_{2} \mathrm{~N}\left(\mathrm{C}_{2} \mathrm{H}_{5}\right)_{2}, 84 \%$

$84, \mathrm{R}=\mathrm{Ph}, \mathrm{R}^{1}$ and $\mathrm{R}^{2}=\left(\mathrm{CH}_{2}\right)_{5}, \mathrm{R}^{3}$ and $\mathrm{R}^{4}=\left(\mathrm{CH}_{2}\right)_{4} \mathrm{O}, 86 \%$

$85, \mathrm{R}=\mathrm{Ph}, \mathrm{R}^{1}$ and $\mathrm{R}^{2}=\left(\mathrm{CH}_{2}\right)_{5}, \mathrm{R}^{3}=\mathrm{H}$, and $\mathrm{R}^{4}=\mathrm{CH}_{2} \mathrm{CH}_{2} \mathrm{~N}\left(\mathrm{CH}_{2}\right)_{4} \mathrm{O}, 83 \%$

Scheme 7 (i) $\mathrm{KOH}, \mathrm{MeOH}, 70{ }^{\circ} \mathrm{C}, 1$ h. (ii) $\mathrm{CH}_{2} \mathrm{Cl}_{2}, \mathrm{H}_{2} \mathrm{O}, \mathrm{HCl}$, r.t. (iii) $\left(\mathrm{C}_{2} \mathrm{H}_{5}\right)_{3} \mathrm{~N}, \mathrm{ClCO}_{2} \mathrm{C}_{2} \mathrm{H}_{5}, \mathrm{CH}_{2} \mathrm{Cl}_{2}, 0{ }^{\circ} \mathrm{C}, 1$ h. (iv) $\mathrm{NHR}{ }^{1} \mathrm{R}^{2}, 0{ }^{\circ} \mathrm{C}, 30$ min then r.t., $90 \mathrm{~min}$. 
of amides were prepared by reacting carboxylic acids 74-76 with ethyl chloroformate and $\mathrm{Et}_{3} \mathrm{~N}$ in dichloromethane to give mixed anhydrides 77, which were coupled with a selection of amines to give amides 78-85 (Scheme 7). ${ }^{35,37}$ Both the acid hydrolysis and the amide couplings proceeded in high yields, typically $75-86 \%$.

Room temperature ${ }^{1} \mathrm{H}$ NMR analysis of the amides 78-85 revealed the vinyl protons mostly as broad singlets, a similar phenomenon observed with the sulfide $\mathrm{OCH}_{2}$ and $\mathrm{SCH}_{2}$, due to interconversion of different conformations of the six-membered endoperoxide ring system. As before, cooling to $-20{ }^{\circ} \mathrm{C}$ revealed the vinyl protons as the expected doublets.

A crystal was grown for compound $\mathbf{8 3}$ by slow evaporation of a $\mathrm{CHCl}_{3}$-hexane mixture and the single-crystal $\mathrm{X}$-ray structure is depicted in Fig. 2 below. The X-ray crystal structure confirms our ${ }^{1} \mathrm{H}$ NMR assignment of trans geometry for the double bond in trioxane 83. (As clearly shown in the X-ray crystal structure, recrystallisation of $\mathbf{8 3}$ from chloroform-hexane has produced the hydrochloride hydrate, and a plausible explanation for this observation is the presence of $\mathrm{HCl}$ in the chloroform solvent.)

\section{Antimalarial properties}

In vitro analysis on 36 selected trioxanes was performed on the 3D7 chloroquine-sensitive parasite isolate of Plasmodium falciparum
(Table 3). ${ }^{38}$ Artemisinin and chloroquine were used as standard positive controls.

From the large volume of data recorded against the 3D7 strain of Plasmodium falciparum, several SAR trends emerge. For spiro 1,2,4-trioxane sulfides $\mathbf{1 5}-\mathbf{1 8}$, the best activity is conferred by fusion to a cyclopentyl or adamantyl ring system. Replacement of the methyl function with a phenyl ring system reduces activity for most analogues prepared (see, for example, 19). An unexpected result was the high potency conferred by fusion of the 1,2,4trioxane heterocycle to a cis-bicyclo[3.3.0]octane: this molecule (29) had excellent activity of $24 \mathrm{nM}$. In spite of this observation, further studies were not performed due to the expense of the cisbicyclo[3.3.0]octane-3,7-dione starting material.

In general, the sulfones expressed reduced activity when compared with the corresponding sulfides (see 16 versus 31, and 15 versus 34). For the vinyl-substituted dispiro 1,2,4-trioxanes, excellent activity was noted for diethyl amides 63, 64 and 65 . Additional analogues with low nanomolar activity include the morpholine analogues $\mathbf{8 1}$ and $\mathbf{8 2}$, and alkyl amine-linked derivative 83. As noted elsewhere, ${ }^{10}$ for the polar vinyl 1,2,4-trioxane series, the adamantylidene fused derivatives express the best level of antimalarial activity.

From the calculated $\operatorname{Clog} P$ and aqueous solubilities it is clear that analogues 63-65 and 79-85 have significantly reduced lipid

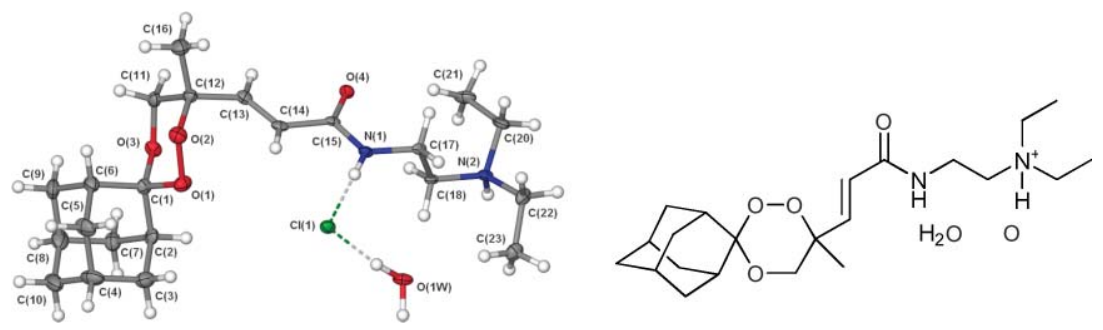

Fig. 2 The asymmetric unit of the single-crystal X-ray structures of the trioxane amide $\mathbf{8 3}\left(\mathrm{HCl} \cdot \mathrm{H}_{2} \mathrm{O}\right)(\mathrm{CCDC} 680268)$. Non- $\mathrm{H}$ atoms are represented by thermal ellipsoids at the $50 \%$ probability level and $\mathrm{H}$-atoms are shown as circles with arbitrary radii.

Table 3 In vitro antimalarial activity versus the chloroquine sensitive 3D7 strain of Plasmodium falciparum and calculated $\log P$ and aqueous solubilities $(\log S)$. Lead compounds are in italics

\begin{tabular}{|c|c|c|c|c|c|c|c|}
\hline Comp. & $\mathrm{IC}_{50} / \mathrm{nM}^{a}$ & $\log P$ & Solubility $/ \mathrm{mg} \mathrm{mL}^{-1}$ & Comp. & $\mathrm{IC}_{50} / \mathrm{nM}^{a}$ & $\log P$ & Solubility $/ \mathrm{mg} \mathrm{mL}^{-1}$ \\
\hline 15 & 110.50 & 4.90 & 5.72 & 63 & 48.32 & 2.76 & 553.86 \\
\hline 16 & 37.91 & 4.46 & 8.47 & 64 & 38.82 & 2.29 & 1356.48 \\
\hline 18 & 59.07 & 5.68 & 0.50 & 66 & 79.21 & 1.98 & 1057.68 \\
\hline 19 & 361.50 & 6.01 & 0.86 & 67 & 129.22 & 2.42 & 499.80 \\
\hline 23 & 113.91 & 4.25 & 12.85 & 68 & 68.29 & 3.20 & 31.56 \\
\hline 24 & 314.00 & 3.41 & 33.54 & 69 & 124.88 & 2.39 & 829.68 \\
\hline 30 & 154.00 & 2.73 & 47.77 & 78 & 250.80 & 1.40 & 3920.36 \\
\hline 31 & 92.90 & 3.07 & 37.17 & 79 & 111.75 & 0.94 & 4188.70 \\
\hline 32 & 136.90 & 3.51 & 25.55 & 80 & 37.03 & 2.03 & 1636.33 \\
\hline 34 & 131.80 & 4.30 & 2.73 & 81 & 27.95 & 2.60 & 85.21 \\
\hline 37 & 108.88 & 2.89 & 87.87 & 82 & 37.80 & 2.19 & 131.57 \\
\hline 39 & 72.00 & 3.70 & 8.28 & 83 & 36.70 & 3.31 & 36.64 \\
\hline
\end{tabular}

${ }^{a}$ See the Experimental section for the description of the assays. IC50 values were averaged values determined from three independent experiments. The $\log P$ and solubilities were calculated using Virtual Computational Chemistry Laboratory (VCCLAB), http://www.vcclab.org, 2005. 
Table 4 In vitro cytotoxicity of selected analogues ${ }^{a}$

\begin{tabular}{lc}
\hline Compound & IC50/ $\mu \mathrm{M}$ \\
\hline $\mathbf{1 6}$ & $>100$ \\
$\mathbf{2 9}$ & $>100$ \\
$\mathbf{3 1}$ & $>100$ \\
$\mathbf{8 2}$ & $>100$ \\
$\mathbf{8 3}$ & $>100$
\end{tabular}

${ }^{a}$ Freshly isolated PBMC, $72 \mathrm{~h}(n=3)$, cytotoxicity assessed by MTT assay.

Table 5 Peter's suppressive test results versus Plasmodium yoelli in mice ${ }^{a}$

\begin{tabular}{lc}
\hline Compound & $\%$ of inhibition at $30 \mathrm{mg} \mathrm{kg}^{-1}$ \\
\hline $\mathbf{1 6}$ & 5 \\
$\mathbf{3 1}$ & 12.0 \\
$\mathbf{3 4}$ & 25.1 \\
$\mathbf{6 5}$ & 65 \\
$\mathbf{8 1}$ & 50 \\
$\mathbf{8 2}$ & 80 \\
Artesunate & 100 \\
Artemether & 100 \\
& \\
a Parasitaemia was determined by microscopic examination of Giemsa- \\
stained blood films taken on day 4. Microscopic counts of blood films \\
from each mouse were processed using spreadsheet (Microsoft Corp.) \\
and expressed as percentage of inhibition from the arithmetic mean \\
parasitaemia of each group in relation to the untreated group. \\
\hline
\end{tabular}

solubility profiles compared with the initial hit molecule 16. The concept of reducing $\mathrm{C} \log P$ in antimalarial endoperoxide drug design has been discussed, ${ }^{39}$ and here the benefits are evident in terms of producing improved lead compounds with encouraging in vitro and in vivo (vide infra) antimalarial activity profiles.

Table 4 lists the in vitro cytotoxicity of analogues 16, 31, 82 and 83 versus human peripheral mono-nuclear type B cells $(n=3)$, where the IC50 values were all greater than $100 \mu \mathrm{M}$. The MTT assays were carried out after $72 \mathrm{~h}$ of drug treatment and it is clear that representative molecules from the sulfide (16), sulfone (31) and vinyl amides $(\mathbf{8 2}$ and $\mathbf{8 3}$ ) have very high therapeutic indices.

A 4-day Peters ${ }^{\text {'40 }}$ test was performed on 16, 31, 34, 81 and 82, and the results are summarized in Table 5 below. The compounds were administered orally by dissolving in standard suspending formula (SSV) ( $0.5 \%$ sodium carboxymethylcellulose, $0.5 \%$ benzyl alcohol, $0.4 \%$ Tween $80,0.9 \% \mathrm{NaCl}$ ), followed by treatment with $0.2 \mathrm{~mL}$ of a solution of the test compound two hours (day 0 ) and on days 1,2 , and 3 post infections.

The sulfides 15-18 were shown to have poor oral antimalarial activity following administration to mice (15, 17 and $18<5 \%$ inhibition (data not shown)). Since oxidative metabolism may have been an issue with this series, we next examined the sulfone derivatives 31 and 34. Although activity was improved, maximum inhibition was never above $20-25 \%$. The vinyl amide adamantanone analogues $\mathbf{6 5}, \mathbf{8 1}$ and $\mathbf{8 2}$ performed somewhat better, with analogue 82 expressing activity approaching the semi-synthetic derivatives artesunate and artemether by oral administration.

\section{Conclusions}

This study exemplifies the value of TOCO chemistry for the synthesis of a diversely functionalised set of 1,2,4-trioxane derivatives. The initial hit sulfide series, although active in vitro, proved to have poor oral antimalarial activity as did their sulfone counterparts. Further medicinal chemistry optimisation of the side chain was successful in terms of reducing the $C \log P$, with analogues 63-65 having significantly reduced lipophilicity compared with initial hit molecule 16. Additional manipulation of the side-chain to enhance polarity (79-85) provided analogues with acceptable Clog $P$ values, low nanomolar activity, low cytotoxicity and, importantly for trioxane 82, good oral activity in the Plasmodium yoelli model of malaria. Based upon the synthetic chemistry reported here, further optimisation of this template should now be possible in order to enhance the oral activity of these molecules further.

\section{Experimental}

All reagents were obtained from commercial suppliers including Aldrich Chemical Co. and Lancaster. Dichloromethane (DCM), triethylamine $\left(\mathrm{Et}_{3} \mathrm{~N}\right)$ and tetrahydrofuran $(\mathrm{THF})$ were freshly distilled before use. The analytical thin layer chromatography was performed on pre-coated silica gel $(0.25 \mathrm{~mm}$ layer of silica gel F254) aluminium sheets. UV light (254 nm) was used for all visualizations and flash column chromatography was performed using Merck 938S Kieselgel 60 Silica gel. All of the IR spectra were run using the Perkin-Elmer 298 infrared spectrophotometer. Solid samples were dissolved in $\mathrm{CHCl}_{3}$ and liquids/oils neat on sodium chloride discs.

${ }^{1} \mathrm{H}$ NMR spectra were recorded using the Bruker (400, 250, and $200 \mathrm{MHz}$ ) NMR spectrophotometers. Spectra were referenced to the residual solvent peak and chemical shifts expressed in ppm from TMS as the internal reference peak. With exception of those stated, all of the NMR was performed at room temperature. The following notations were used to describe the multiplicity; $b$, broad, s, singlet, bs, broad-singlet, d, doublet, dd, double-doublet, $\mathrm{t}$, triplet, q, quartet, $\mathrm{m}$, multiplet, and coupling constants were recorded in hertz.

Mass spectra were recorded between $20-70 \mathrm{eV}$ using a VG7070E and/or Micromass LCT mass spectrometers. The molecular ion $\mathrm{M}^{+}$with intensities in parenthesis is given followed by peaks corresponding to major fragment losses. Melting points are expressed in degree Celsius $\left({ }^{\circ} \mathrm{C}\right)$ and performed using the Gallemkamp melting point apparatus and capillary tubes. The antiparasitic properties (IC50, 4 day Peters' experiment) were performed at the University of Liverpool and London Schools of Tropical Medicine. X-ray crystal structure measurements were performed at the Department of Chemistry the University of Liverpool.

\section{In vitro sensitivity assays}

Drug susceptibilities were assessed by the measurement of fluorescence after the addition of SYBR Green I as previously described by Smilkstein et al. ${ }^{41}$ Drug IC50s were calculated from the $\log$ of the dose/response relationship, as fitted with Grafit software (Erithacus Software, Kent, United Kingdom). Results are given as the mean of at least three separate experiments. For the fluorescence assay, after $48 \mathrm{~h}$ of growth, $100 \mu \mathrm{L}$ of SYBR Green $\mathrm{I}$ in lysis buffer $(0.2 \mu \mathrm{L}$ of SYBR Green $\mathrm{I} / \mathrm{mL}$ of lysis buffer) was added to each well, and the contents were mixed until no visible erythrocyte sediment remained. After $1 \mathrm{~h}$ of incubation in the dark at room temperature, fluorescence was measured with 
a Varioskan fluorescence multiwell plate reader from Thermo Electron Corporation with excitation and emission wavelengths of 485 and $530 \mathrm{~nm}$, respectively.

\section{Representative procedure for the preparation of trioxane sulfides 15-30}

Preparation of 3-(4-chloro-phenylsulfanylmethyl)-3-methyl1,2,4-trioxa-spiro[5.5]undecane (15). A 2-necked $500 \mathrm{~mL}$ round bottom flask was charged with a solution of 2-methyl-2-propenol (500 mg, $0.58 \mathrm{~mL}, 0.69 \mathrm{mmol})$ and AIBN (77.5mg, 4.72mmol) in $\mathrm{CH}_{3} \mathrm{CN}(115 \mathrm{~mL})$. The reaction vessel was flushed with oxygen for several minutes at $0{ }^{\circ} \mathrm{C}$ then stoppered and kept under a positive pressure of pure oxygen, with the aid of two oxygen balloons. The reaction mixture was vigorously stirred and UV irradiated at $0{ }^{\circ} \mathrm{C}$ using an externally mounted $100 \mathrm{~W}$ BLACK-RAY UV lamp at a distance of 5-7 cm, with the simultaneous addition of 4-chlorothiophenol (1250 mg, $8.64 \mathrm{~mol}, 3.13$ equiv.) solution in $\mathrm{CH}_{3} \mathrm{CN}(65 \mathrm{~mL})$ over a period of $30 \mathrm{~min}$. After completion of the addition, the reaction was stirred at $0{ }^{\circ} \mathrm{C}$ for $4-6 \mathrm{~h}$ or until consumption of starting materials (monitored by tlc). The reaction vessel was then cooled to $-10{ }^{\circ} \mathrm{C}$, flushed with nitrogen and a solution of cyclohexanone (1703 mg, $17.35 \mathrm{mmol}, 1.63 \mathrm{~mL}$ ) in DCM $(65 \mathrm{~mL})$ was added, followed by a catalytic amount of tosic acid. The mixture was stirred at $-10{ }^{\circ} \mathrm{C}$, and then allowed to warm slowly to room temperature overnight. Concentration in vacuo and purification by flash column chromatography using ethyl acetate-hexane $\left(1: 5, \mathrm{v} / \mathrm{v}, R_{\mathrm{f}} 0.44\right)$ gave $15(1.46 \mathrm{~g}, 64 \%)$ as a white powder. $\mathrm{Mp} 57-59 .{ }^{\circ} \mathrm{C} v_{\max }\left(\mathrm{CHCl}_{3}\right) / \mathrm{cm}^{-1} 810.2,920.1$, 1007.2, 1090.5, 1446.6, 1473.1, 2855.3, 2931.1, 3006.8. ${ }^{1} \mathrm{H}$ NMR $\left(400 \mathrm{MHz}, \mathrm{CDCl}_{3}, 0{ }^{\circ} \mathrm{C}\right) \delta_{\mathrm{H}} 1.14\left(\mathrm{~s}, 3 \mathrm{H}, \mathrm{CH}_{3}\right), 1.33-1.57(\mathrm{~m}, 8 \mathrm{H}$, cyclohexyl), 1.90 (bs, 1H, cyclohexyl), 2.14 (bs, 1H, cyclohexyl), $3.48\left(\mathrm{~d}, 1 \mathrm{H}, J=13.1 \mathrm{~Hz}, \mathrm{SCH}_{2}\right), 3.62\left(\mathrm{~d}, 1 \mathrm{H}, J=13.1 \mathrm{~Hz}, \mathrm{SCH}_{2}\right)$, $3.69\left(\mathrm{~d}, 1 \mathrm{H}, J=12.1 \mathrm{~Hz}, \mathrm{OCH}_{2}\right), 3.88(\mathrm{~d}, 1 \mathrm{H}, J=12.1 \mathrm{~Hz}$, $\left.\mathrm{OCH}_{2}\right), 7.24$ (d, 2H, $\left.J=8.6 \mathrm{~Hz}, \mathrm{Ar}\right), 7.35$ (d, 2H, $\left.J=8.6 \mathrm{~Hz}, \mathrm{Ar}\right)$; ${ }^{13} \mathrm{C} \mathrm{NMR}\left(100 \mathrm{MHz}, \mathrm{CDCl}_{3}\right) . \delta_{\mathrm{C}} 20.60,22.60,22.7,25.9,33.8$, $64.2,79.4,102.7,129.4,129.7,131.0,131.7 . \mathrm{MS}(\mathrm{ES}+)[\mathrm{M}+\mathrm{Na}]^{+}$ (100) 367.1, [2M + Na $]^{+}$679.2. HRMS calculated for 351.0798 $\mathrm{C}_{16} \mathrm{H}_{21} \mathrm{O}_{3} \mathrm{NaS}^{35} \mathrm{Cl}$, found 351.0803 . Elemental analysis $\mathrm{C}: 58.62$, H: 6.48 (required values C: 58.44, H:6.44).

\section{Representative procedure for preparation of sulfones $31-42$}

Preparation of 8-(4-chloro-benzenesulfonylmethyl)-8-methyl6,7,10-trioxa-spiro[4.5]-decane (31). A solution of sulfide 16 (0.1 g, $0.32 \mathrm{mmol}, 1$ equiv.) and $m \mathrm{CPBA}(0.16 \mathrm{~g}, 0.95 \mathrm{mmol}$, 2.2 equiv.) in DCM (2 mL) was stirred for $4-6 \mathrm{~h}$ at room temperature. After consumption of the more polar intermediate (monitored by tlc), the mixture was poured into a saturated solution of $5 \% \mathrm{~K}_{2} \mathrm{CO}_{3}$. The mixture was extracted with DCM and the organic layer separated, dried over $\mathrm{MgSO}_{4}$ and evaporated. Purification of the residue by flash column chromatography using ethyl acetate-hexane ( $1: 4$, v/v, $\left.R_{\mathrm{f}} 0.58\right)$ gave 31 in $(0.08 \mathrm{~g}, 76 \%)$ as white powder. $\mathrm{Mp} 114-116^{\circ} \mathrm{C}$. $v_{\max }\left(\mathrm{CHCl}_{3}\right) / \mathrm{cm}^{-1} 820.0,963.6$, $1008.7,1086.6,1144.0,1316.2,1390.0,1472.0,1578.6,2871.3$, 2969.7, 3010.7. ${ }^{1} \mathrm{H} \mathrm{NMR}\left(400 \mathrm{MHz}, \mathrm{CDCl}_{3}\right) \delta_{\mathrm{H}} 1.46\left(\mathrm{~s}, 3 \mathrm{H}, \mathrm{CH}_{3}\right)$, 1.52-1.84 (m, 8H, cyclopentyl), $3.67\left(\mathrm{~d}, 2 \mathrm{H}, J=11.9 \mathrm{~Hz}, \mathrm{OCH}_{2}\right)$, $3.90\left(\mathrm{~d}, 1 \mathrm{H}, J=14.1 \mathrm{~Hz}, \mathrm{SO}_{2} \mathrm{CH}_{2}\right), 4.00(\mathrm{~d}, 1 \mathrm{H}, J=12.1 \mathrm{~Hz}$, $\left.\mathrm{SO}_{2} \mathrm{CH}_{2}\right), 7.55(\mathrm{~d}, 2 \mathrm{H}, J=8.7 \mathrm{~Hz}, \mathrm{Ar}), 7.90(\mathrm{~d}, 2 \mathrm{H}, J=8.7 \mathrm{~Hz}, \mathrm{Ar})$.
${ }^{13} \mathrm{C} \mathrm{NMR}\left(100 \mathrm{MHz}, \mathrm{CDCl}_{3}\right), \delta_{\mathrm{C}} 20.2,23.5,24.9,30.1,58.9,67.6$, 114.9, 129.8, 139.9, 140.8. MS (ES+) $[\mathrm{M}+\mathrm{Na}]^{+}(100) 369,[2 \mathrm{M}+$ $\mathrm{Na}]^{+}$715/717; HRMS calculated for $369.0539 \mathrm{C}_{15} \mathrm{H}_{19} \mathrm{O}_{5} \mathrm{NaSCl}$, found 369.0532. Elemental analysis $\mathrm{C}: 51.96, \mathrm{H}: 5.48$ (required values $\mathrm{C}: 51.95, \mathrm{H}: 5.52)$.

\section{General procedure for the preparation of sulfoxides $43-48$}

A solution of the sulfide ( 1 equiv.) and $m$ CPBA ( 1 equiv.) in DCM was stirred for 4-6 h at room temperature. The mixture was poured into a saturated solution of $5 \% \mathrm{~K}_{2} \mathrm{CO}_{3}$ and extracted with DCM. The organic layer was separated, dried over $\mathrm{MgSO}_{4}$ and evaporated. The mixtures of the two enantiomers were used without purification for the Pummerer reaction.

\section{General procedure for the preparation of aldehydes 49-54}

Preparation of 8-methyl-6,7,10-trioxa-spiro[4.5]decane-8-carbaldehyde (49). To a solution of the sulfoxide $44(1 \mathrm{~g}, 3.02 \mathrm{mmol})$ at $0{ }^{\circ} \mathrm{C}$ in $\mathrm{CH}_{3} \mathrm{CN}(5 \mathrm{~mL}), 2,6$-lutidine $(1.5 \mathrm{~g}, 12.8 \mathrm{mmol})$ and trifluoroacetic anhydride (TFAA) $(1.63 \mathrm{~g}, 11.65 \mathrm{mmol})$, in $\mathrm{CH}_{3} \mathrm{CN}$ $(12 \mathrm{~mL})$ were added. The mixture was stirred at room temperature for $3 \mathrm{~h}$ and extracted with ethyl acetate $(50 \mathrm{~mL})$. The organic layer was dried in $\mathrm{MgSO}_{4}$ and the solvent removed under reduced pressure to give the aldehyde. Purification was achieved by flash column chromatography using ethyl acetate-hexane $\left(1: 9, \mathrm{v} / \mathrm{v}, R_{\mathrm{f}}\right.$ $0.70)$ as eluent to give $49(0.53 \mathrm{~g}, 89 \%)$ as a colourless oil. ${ }^{1} \mathrm{H}$ NMR (400 MHz, $\left.\mathrm{CDCl}_{3}\right) \delta_{\mathrm{H}} 1.07\left(\mathrm{~s}, 3 \mathrm{H}, \mathrm{CH}_{3}\right), 1.60-1.82(\mathrm{~m}$, $6 \mathrm{H}$, cyclohexyl), 1.86-1.96 (m, $1 \mathrm{H}$, cyclopentyl), 2.41-2.51 (m, $1 \mathrm{H}$, cyclopentyl), $3.70\left(\mathrm{~d}, 1 \mathrm{H}, J=11.6 \mathrm{~Hz}, \mathrm{CH}_{2} \mathrm{O}\right), 4.18(\mathrm{~d}, 1 \mathrm{H}, J=$ $\left.11.6 \mathrm{~Hz}, \mathrm{CH}_{2} \mathrm{O}\right), 9.90$ (s, $\left.1 \mathrm{H}, \mathrm{CHO}\right){ }^{13} \mathrm{C} \mathrm{NMR}\left(400 \mathrm{MHz}, \mathrm{CDCl}_{3}\right.$ ), $\delta_{\mathrm{C}} 16.7,23.5,37.3,64.3,84.7,114.7,203.2 \mathrm{MS}(\mathrm{ES}+)[\mathrm{M}+\mathrm{Na}]^{+}$ (100) 209.1, HRMS calculated for $209.0814 \mathrm{C}_{9} \mathrm{H}_{14} \mathrm{O}_{4} \mathrm{Na}$, found 209.0817 .

\section{Representative procedure for the preparation of $60-62$}

Preparation of 3-methyl-3-styryl-1,2,5-trioxa-spiro[5.11]heptadecane 60. To a stirred suspension of benzyltriphenylphosphonium bromide $(0.51 \mathrm{~g}, 1.18 \mathrm{mmol})$ in THF $(2 \mathrm{~mL})$ was added NHMDS (1.18 mL, $1.18 \mathrm{mmol}, 1 \mathrm{M}$ solution in THF) via syringe. The reaction mixture was allowed to stir at room temperature for $15 \mathrm{~min}$, and then a solution of 3-methyl-1,2,5-trioxaspiro[5.11]heptadecane-3-carbaldehyde $(0.21 \mathrm{~g}, 0.738 \mathrm{mmol})$ in THF ( $2 \mathrm{~mL})$ was added. After an additional $1 \mathrm{~h}$, the reaction was quenched with saturated aq. $\mathrm{NaHCO}_{3}$, extracted with ether, washed with brine, dried $\left(\mathrm{Na}_{2} \mathrm{SO}_{4}\right)$ and concentrated in vacuo. The product was purified by flash chromatography to give the desired compound as a white solid in $69 \%$ yield. The product was purified by column chromatography using ethyl acetate-hexane $(25: 75$, $\left.\mathrm{v} / \mathrm{v}, R_{\mathrm{f}} 0.78\right)$ to give the product as a white solid. Mp $86-87^{\circ} \mathrm{C}$. ${ }^{1} \mathrm{H} \mathrm{NMR}\left(400 \mathrm{MHz}, \mathrm{CDCl}_{3}\right) \delta_{\mathrm{H}} 7.32(\mathrm{~m}, 5 \mathrm{H}$, aromatic), $7.11(\mathrm{~d}$, $J=12.67 \mathrm{~Hz}, 1 \mathrm{H}$, trans olefin- $\mathrm{C}=\mathrm{CH}), 6.72(\mathrm{~d}, J=12.67 \mathrm{~Hz}$, trans olefin), 3.90 (bs, $\left.1 \mathrm{H},-\mathrm{OCH}_{2}\right), 3.61$ (bs, $\left.1 \mathrm{H},-\mathrm{OCH}_{2}\right), 1.28$ (m, 22H, cyclodeodecane moiety), $1.23\left(\mathrm{~s}, 3 \mathrm{H},-\mathrm{CH}_{3}\right) \cdot{ }^{13} \mathrm{C} \mathrm{NMR}$ $\left(100 \mathrm{MHz}, \mathrm{CDCl}_{3}\right)$ 134.17, 129.17, 128.90, 128.29, 126.92, 126.84, $106.55,79.41,60.71,40.70,31.94,26.36,22.99$ and 21.34. MS $(\mathrm{ES}+) \mathrm{m} / z 381.3[\mathrm{M}+\mathrm{Na}]^{+}(98), 413.3\left[\mathrm{M}+\mathrm{CH}_{3} \mathrm{OH}+\mathrm{Na}\right]^{+}(62)$. HRMS $m / z$ calcd for $\mathrm{C}_{23} \mathrm{H}_{34} \mathrm{O}_{3} \mathrm{Na}[\mathrm{M}+\mathrm{Na}]^{+} 381.2406$ found, 
381.2419. Elemental analysis C: $77.03, \mathrm{H}: 9.58$ (required values C: 77.05, H: 9.56).

\section{Representative procedure for the preparation of acrylamides 63-65}

Preparation of $(E / Z)-N, N$-diethyl-3-(3-methyl-1,2,5-trioxaspiro[5.5] undec-3-yl)-acrylamide (63). To a mixture of $\mathrm{Ph}_{3} \mathrm{P}^{+}=\mathrm{CHCON}\left(\mathrm{C}_{2} \mathrm{H}_{5}\right)_{2} \mathrm{Br}^{-}(0.37 \mathrm{~g}, 0.99 \mathrm{mmol})$ in water (3 $\mathrm{mL})$ and aldehyde $52(0.2 \mathrm{~g}, 0.97 \mathrm{mmol})$ in DCM $(10 \mathrm{~mL})$, was added drop-wise a solution of $\mathrm{NaOH}(0.18 \mathrm{~g}, 0.46 \mathrm{mmol})$ in water $(1 \mathrm{~mL})$. The mixture was stirred for a few minutes and the organic layer was separated, dried over $\mathrm{MgSO}_{4}$, filtered and evaporated. The resulting residue was passed through a silica gel column (EtOAc-Hex 1:1) to remove the triphenylphosphine oxide. Evaporation of the solvent gave $\mathbf{6 3}$ as colourless oil.

Major fraction (trans-isomer). This fraction was collected in $40 \%$ as a colourless oil. $v_{\max }$ (neat) $/ \mathrm{cm}^{-1} 923.4,1088.7,1139.8$, $1277.5,1360.1,1430.9,1446.7,1619.8,1659.1,2860.5,2931.3$, 2962.7. ${ }^{1} \mathrm{H} \mathrm{NMR}\left(400 \mathrm{MHz}, \mathrm{CDCl}_{3}\right) \delta_{\mathrm{H}} 1.10-1.24\left(\mathrm{~m}, 9 \mathrm{H}, \mathrm{CH}_{3}\right)$, 1.40-1.70 (m, 8H, cyclohexyl), 1.80-2.30 (m, 2H, cyclohexyl), 3.32$3.52\left(\mathrm{~m}, 4 \mathrm{H}, \mathrm{NCH}_{2}\right), 3.82$ (bs, $\left.2 \mathrm{H}, \mathrm{CH}_{2} \mathrm{O}\right), 6.68$ (bs, $\left.1 \mathrm{H}, \mathrm{CH}\right)$, 6.85 (bs, $1 \mathrm{H}, \mathrm{CH}) .{ }^{13} \mathrm{C} \mathrm{NMR}\left(100 \mathrm{MHz}, \mathrm{CDCl}_{3}\right), \delta_{\mathrm{C}} 13.5,15.3$, 22.7, 24.3, 41.3, 42.7, 65.4, 79.2, 102.7, 122.3, 141.9, 167.3. MS $(\mathrm{ES}+),[\mathrm{M}+\mathrm{Na}]^{+}$(100) 366.2; HRMS calculated for 320.1838 $\mathrm{C}_{16} \mathrm{H}_{27} \mathrm{NO}_{4} \mathrm{Na}$, found 320.1824 .

Minor fraction (cis-isomer). This fraction was collected in 5\% as a colourless oil. This compound was purified by flash column chromatography using ethyl acetate-hexane $\left(1: 1, \mathrm{v} / \mathrm{v}, R_{\mathrm{f}} 0.44\right)$ as eluent. $v_{\max }$ (neat) $/ \mathrm{cm}^{-1} 923.4,1088.7,1143.7,1265.7,1446.7$, 1462.4, 1619.8, 2868.3, 2939.1, 2970.6. ${ }^{1} \mathrm{H}$ NMR (400 MHz, $\left.\mathrm{CDCl}_{3}\right) \delta_{\mathrm{H}} 1.12-1.23\left(\mathrm{~m}, 9 \mathrm{H}, \mathrm{CH}_{3}\right), 1.30-1.65(\mathrm{~m}, 10 \mathrm{H}$, cyclohexyl), 3.31-3.51 (m, $\left.4 \mathrm{H}, \mathrm{NCH}_{2}\right), 3.82\left(\mathrm{bs}, 1 \mathrm{H}, \mathrm{CH}_{2} \mathrm{O}\right), 4.15(\mathrm{~d}, 1 \mathrm{H}, J=$ $11.0 \mathrm{~Hz}, \mathrm{CH}_{2} \mathrm{O}$ ), 6.08 (d, $\left.1 \mathrm{H}, J=12.9 \mathrm{~Hz}, \mathrm{CH}\right), 6.25$ (bs, $1 \mathrm{H}$, $\mathrm{CH}) .{ }^{13} \mathrm{C} \mathrm{NMR}\left(100 \mathrm{MHz}, \mathrm{CDCl}_{3}\right) \delta_{\mathrm{C}} 13.0,14.3,22.8,25.9,39.6$, 43.1, 65.2, 81.0, 102.4, 123.7, 141.9, 167.3. MS (ES+) $[\mathrm{M}+\mathrm{K}]^{+}$ (100) 366.2, HRMS calculated for $336.1553 \mathrm{C}_{16} \mathrm{H}_{27} \mathrm{NO}_{4} \mathrm{~K}$, found 336.1574 .

Representative procedure for the synthesis of compounds 66-73

Preparation of $(E)$-3-(8-methyl-6,7,10-trioxa-spiro[4.5]dec-8-yl)acrylic acid methyl ester (66). To a solution of the aldehyde 49 $(0.38 \mathrm{~g}, 2.04 \mathrm{mmol})$ in DCM $(15 \mathrm{~mL})$ was added $\mathrm{Ph}_{3} \mathrm{P}=\mathrm{CHCO}_{2} \mathrm{Me}$ $(0.73 \mathrm{~g}, 2.19 \mathrm{mmol})$ at room temperature. The reaction was stirred at this temperature for $3 \mathrm{~h}$ and was subsequently concentrated and chromatographed using hexane-ethyl acetate $\left(1: 4, \mathrm{v} / \mathrm{v}, R_{\mathrm{f}} 0.60\right)$ as eluent on a silica gel to give $66(0.31 \mathrm{~g}, 62 \%)$ as a colourless oil. $v_{\max }$ (neat) $/ \mathrm{cm}^{-1} 861.0,971.8,1090.7,1197.3,1283.4,1312.1$, 1431.0, 1656.5, 1722.2, 2871.3, 2953.3. ${ }^{1} \mathrm{H}$ NMR $(400 \mathrm{MHz}$, $\left.\mathrm{CDCl}_{3}\right) \delta_{\mathrm{H}} 1.15\left(\mathrm{bs}, 3 \mathrm{H}, \mathrm{CH}_{3}\right), 1.45-1.90(\mathrm{~m}, 8 \mathrm{H}$, cyclopentyl), 3.78 (s, 3H, $\mathrm{CH}_{3} \mathrm{O}$ ), 3.85 (s, 2H, $\mathrm{CH}_{2} \mathrm{O}$ ), 6.15 (bs, $1 \mathrm{H}, \mathrm{CH}$ ), 7.18 (bs, $1 \mathrm{H}, \mathrm{CH}) .{ }^{13} \mathrm{C} \mathrm{NMR}\left(100 \mathrm{MHz}, \mathrm{CDCl}_{3}\right) \delta_{\mathrm{C}} 21.8,23.8,37.4,52.1$, $67.8,78.9,114.7,122.4,149.1,167.0 . \mathrm{MS}(\mathrm{ES}+),[\mathrm{M}+\mathrm{Na}]^{+}(100)$ 265, HRMS calculated for $265.1052 \mathrm{C}_{12} \mathrm{H}_{18} \mathrm{O}_{5} \mathrm{Na}$, found 265.1058.

\section{Representative procedure for the synthesis of carboxylic acids 74-76}

Preparation of $(E)$-3-(8-methyl-6,7,10-trioxa-spiro[4.5]dec-8-yl)acrylic acid (74). Ethyl ester $66(0.6037 \mathrm{~g}, 2.4 \mathrm{mmol})$ was hydrolysed in $\mathrm{MeOH}(24 \mathrm{~mL})$ at $70{ }^{\circ} \mathrm{C}$ with potassium hydroxide $(0.74 \mathrm{~g}, 13.1 \mathrm{mmol})$ and water $(3 \mathrm{~mL})$. After an hour heating, the reaction mixture was cooled and diluted with DCM $(30 \mathrm{~mL})$ and water $(12 \mathrm{~mL})$. The aqueous layer was acidified with concentrated hydrochloric acid $(3 \mathrm{~mL})$ and further extracted with DCM. The combined organic layers were washed with water, brine, dried over $\mathrm{Na}_{2} \mathrm{SO}_{4}$ and evaporated to dryness. Purification by flash column chromatography using ethyl acetate: dichoromethane $(1: 1, \mathrm{v} / \mathrm{v}$, $\left.R_{\mathrm{f}} 0.2\right)$ as eluent gave $74(0.46 \mathrm{~g}, 86 \%)$ as white powder. ${ }^{1} \mathrm{H}$ NMR $\left(400 \mathrm{MHz}, \mathrm{CDCl}_{3}\right) \delta_{\mathrm{H}} 1.22\left(\mathrm{bs}, 3 \mathrm{H}, \mathrm{CH}_{3}\right), 1.61-1.92(\mathrm{~m}, 8 \mathrm{H}$, cyclopentyl), 3.70-3.92 (m, 2H, $\left.\mathrm{CH}_{2} \mathrm{O}\right), 6.20$ (bs, $\left.1 \mathrm{H}, \mathrm{CH}\right), 7.30$ (bs, 1H, CH), 10.70 (bs, $1 \mathrm{H}, \mathrm{OH}) .{ }^{13} \mathrm{C} \mathrm{NMR}\left(100 \mathrm{MHz}, \mathrm{CDCl}_{3}\right.$ ), $\delta_{\mathrm{C}} 21.6,23.6,38.7,67.7,78.9,114.9,122.0,151.4,171.7 . \mathrm{MS}(\mathrm{ES}-)$ $[\mathrm{M}-\mathrm{H}]^{-}(100) 227.1$.

\section{Representative procedure for the synthesis of the amides 78-85}

Preparation of $(E)-3-(8-m e t h y l-6,7,10-$ trioxa-spiro[4.5]dec-8-yl)1-morpholin-4-yl-propenone (78). A solution of acid 77 (0.12 g, $0.53 \mathrm{mmol})$ in dry DCM $(27 \mathrm{~mL})$, with added triethylamine $(0.06 \mathrm{~g}$, $0.008 \mathrm{~mL}, 0.53 \mathrm{mmol})$ and ethylchloroformate $(0.008 \mathrm{~g}, 0.07 \mathrm{~mL}$, $0.7 \mathrm{mmol})$ was stirred for $60 \mathrm{~min}$ at $0{ }^{\circ} \mathrm{C}$. Morpholine $(0.09 \mathrm{~g}$, $0.09 \mathrm{~mL}, 1.06 \mathrm{mmol}$ ) was added and the solution allowed to stir for $30 \mathrm{~min}$ at $0{ }^{\circ} \mathrm{C}$ before being warmed to room temperature. After $90 \mathrm{~min}$, it was diluted with water and extracted with DCM. The organic extract was washed with brine, and dried over anhydrous $\mathrm{Na}_{2} \mathrm{SO}_{4}$. The crude product was purified by flash chromatography using ethyl acetate-hexane $\left(1: 1, \mathrm{v} / \mathrm{v}, R_{\mathrm{f}} 0.17\right)$ as eluent to give $78(0.13 \mathrm{~g}, 83 \%)$ as a white powder. $\mathrm{Mp} 68-$ $70{ }^{\circ} \mathrm{C} . v_{\max }\left(\mathrm{CHCl}_{3}\right) / \mathrm{cm}^{-1} 1433.2,1614.3,1655.1,2858.9,2922.3$, 2976.5. ${ }^{1} \mathrm{H}$ NMR $\left(400 \mathrm{MHz}, \mathrm{CDCl}_{3}\right) \delta_{\mathrm{H}} 1.22\left(\mathrm{bs}, 3 \mathrm{H}, \mathrm{CH}_{3}\right), 1.59-$ 1.92 (m, 8H, cyclopentyl), 3.59 (bs, $\left.2 \mathrm{H}, \mathrm{CH}_{2} \mathrm{O}\right), 3.65-3.74(\mathrm{~m}, 6 \mathrm{H}$, $\left.\mathrm{NCH}_{2} / \mathrm{CH}_{2} \mathrm{O}\right), 3.83(\mathrm{~d}, 1 \mathrm{H}, J=15.5 \mathrm{~Hz}, \mathrm{CH}), 6.50(\mathrm{~d}, 1 \mathrm{H}, J=$ $15.5 \mathrm{~Hz}, \mathrm{CH}), 6.80(\mathrm{bs}, 1 \mathrm{H}, \mathrm{CH}) .{ }^{13} \mathrm{C} \mathrm{NMR}\left(100 \mathrm{MHz}, \mathrm{CDCl}_{3}\right) \delta_{\mathrm{C}}$ 21.0, 24.5, 42.4, 46.4, 66.8, 67.5, 78.7, 114.3, 121.3, 144.7, 165.4. MS (ES+) $[\mathrm{M}+\mathrm{Na}]^{+}(100) 320.1$, and $[2 \mathrm{M}+\mathrm{Na}]^{+}$617.2 HRMS calculated for $320.1474 \mathrm{C}_{15} \mathrm{H}_{23} \mathrm{NO}_{5} \mathrm{Na}$, found 320.1480 . Elemental analysis C: 60.83, H: 7.82 (required values C: 60.59, H: 7.80).

\section{Crystal data for 35 dimethylformamide solvate (CCDC 680267)}

$\mathrm{C}_{24} \mathrm{H}_{30} \mathrm{ClNO}_{6} \mathrm{~S}, M=496.00$, colourless plate, $0.50 \times 0.20 \times$ $0.04 \mathrm{~mm}^{3}$, triclinic, space group $P \overline{1}$ (No. 2), $a=5.6889$ (13), $b=$ 13.461(3), $c=16.663(4) \AA, \alpha=67.393(4), \beta=80.926(5), \gamma=$ 83.493(4) ${ }^{\circ}, V=1161.3(5) \AA^{3}, Z=2, D_{\mathrm{c}}=1.418 \mathrm{~g} \mathrm{~cm}^{-3}, F_{000}=524$, Bruker D8 diffractometer with APEX detector, Mo-K $\alpha$ radiation, $\lambda=0.71073 \AA, T=100(2) \mathrm{K}, 2 \theta_{\max }=53.5^{\circ}, 6737$ reflections collected, 4786 unique $\left(R_{\text {int }}=0.0224\right)$. Final GooF $=1.068, R_{1}=$ $0.0457, \mathrm{w} R_{2}=0.0963, R$ indices based on 3862 reflections with $I>2 \sigma(I)$ (refinement on $F^{2}$ ), 300 parameters, 0 restraints. Lp and absorption corrections applied, $\mu=0.296 \mathrm{~mm}^{-1}$.

\section{Crystal data for 83 hydrochloride hydrate $\left(\mathrm{CHCl}_{3} /\right.$ hexane $)$ (CCDC 680268)}

$\mathrm{C}_{22} \mathrm{H}_{39} \mathrm{ClN}_{2} \mathrm{O}_{5}, M=447.00$, colourless plate, $0.50 \times 0.40 \times$ $0.10 \mathrm{~mm}^{3}$, monoclinic, space group $P 2_{1} / c$ (No. 14), $a=18.705(3)$, $b=7.6876(13), c=16.257(3) \AA, \beta=93.288(3)^{\circ}, V=2333.9(7) \AA^{3}$, $Z=4, D_{\mathrm{c}}=1.272 \mathrm{~g} \mathrm{~cm}^{-3}, F_{000}=968$, Bruker D8 diffractometer 
with APEX detector, Mo-K $\alpha$ radiation, $\lambda=0.71073 \AA$, $T=100(2)$ $\mathrm{K}, 2 \theta_{\max }=50.7^{\circ}, 14079$ reflections collected, 4241 unique $\left(R_{\text {int }}=\right.$ $0.0506)$. Final $G o o F=1.143, R_{1}=0.0730, \mathrm{w} R_{2}=0.1611, R$ indices based on 3573 reflections with $I>2 \sigma(I)$ (refinement on $F^{2}$ ), 293 parameters, 3 restraints. Lp and absorption corrections applied, $\mu=0.198 \mathrm{~mm}^{-1}$.

\section{Acknowledgements}

The authors thank the BBSRC (SAW, PON, PG Grants BB/C006321/1 and 26/B13581), the EU (Antimal FP6 Malaria Drugs Initiative) and Romark (RA) for generous funding of this work.

\section{References}

1 N. J. White, J Clin Invest, 2004, 113, 1084-1092.

2 T. Jelinek, A. M. Renn, J. Curtis, M. T. Duraisingh, M. M. Lemnge, J. Mhina, I. C. Bygbjerg and D. C. Warhurst, Trop. Med. Int. Health, 1997, 2, 1075-1079.

3 T. K. Mutabingwa, Acta Trop., 2005, 95, 305-315.

4 Antimalarial drug combination therapy: Report of WHO technical consultation, World Health Organization, Geneva, 4-5 April 2001 (WHO/CDS/RBM/2001.35).

5 Expert Rev. of Anti-Infect Ther., 2009, 7, 504.

6 J. Golenser, J. H. Waknine, M. Krugliak, N. H. Hunt and G. E. Grau, Int. J. Parasitol., 2006, 36, 1427-1441.

7 J. A. Vroman, M. Alvim-Gaston and M. A. Avery, Curr. Pharm. Des., 1999, 5, 101-138.

8 C. Singh, Tetrahedron Lett., 1990, 31, 6901-6902.

9 A. G. Griesbeck, T. T. El-Idreesy, M. Fiege and R. Brun, Org. Lett., 2002, 4, 4193-4195.

10 Y. Q. Tang, Y. X. Dong, X. F. Wang, K. Sriraghavan, J. K. Wood and J. L. Vennerstrom, J. Org. Chem., 2005, 70, 5103-5110.

11 B. Camuzat-Dedenis, O. Provot, L. Cointeaux, V. Perroux, J. F. Berrien, C. Bories, P. M. Loiseau and J. L. Mayrargue, Eur. J. Med. Chem., 2001, 36, $837-842$.

12 G. H. Posner, C. H. Oh, L. Gerena and W. K. Milhous, J. Med. Chem., 1992, 35, 2459-2467.

13 A. J. Bloodworth and A. Shah, J. Chem. Soc., Chem. Commun., 1991, 947-948.

14 M. Jung, X. Li, D. A. Bustos, H. N. Elsohly, J. D. McChesney and W. K. Milhous, J. Med. Chem., 1990, 33, 1516-1518.

15 J. Kim, H. Bin Li, A. S. Rosenthal, D. P. Sang, T. A. Shapiro, M. D. Bachi and G. H. Posner, Tetrahedron, 2006, 62, 4120-4127.

16 M. D. Bachi, E. E. Korshin, R. Hoos, A. M. Szpilman, P. Ploypradith, S. J. Xie, T. A. Shapiro and G. H. Posner, J. Med. Chem., 2003, 46, 2516-2533.

17 E. E. Korshin, R. Hoos, A. M. Szpilman, L. Konstantinovski, G. H. Posner and M. D. Bachi, Tetrahedron, 2002, 58, 2449-2469.

18 P. M. O’Neill, E. Verissimo, S. A. Ward, J. Davies, E. E. Korshin, N. Araujo, M. D. Pugh, M. L. S. Cristiano, P. A. Stocks and M. D. Bachi, Bioorg. Med. Chem. Lett., 2006, 16, 2991-2995.

19 P. M. O’Neill, A. Mukhtar, S. A. Ward, J. F. Bickley, J. Davies, M. D. Bachi and P. A. Stocks, Org. Lett., 2004, 6, 3035-3038.
20 P. M. O’Neill, P. A. Stocks, M. D. Pugh, N. C. Araujo, E. E. Korshin, J. F. Bickley, S. A. Ward, P. G. Bray, E. Pasini, J. Davies, E. Verissimo and M. D. Bachi, Angew. Chem., Int. Ed., 2004, 43, 4193-4197.

21 R. Amewu, A. V. Stachulski, N. G. Berry, S. A. Ward, J. Davies, G. Labat, J. F. Rossignol and P. M. O'Neill, Bioorg. Med. Chem. Lett., 2006, 16, 6124-6130.

22 G. H. Posner, H. O’Dowd, P. Ploypradith, J. N. Cumming, S. Xie and T. A. Shapiro, J. Med. Chem., 1998, 41, 2164-2167.

23 G. H. Posner, J. P. Maxwell, H. O’Dowd, M. Krasavin, S. J. Xie and T. A. Shapiro, Bioorg. Med. Chem., 2000, 8, 1361-1370.

24 G. H. Posner, H. O'Dowd, T. Caferro, J. N. Cumming, P. Ploypradith, S. J. Xie and T. A. Shapiro, Tetrahedron Lett., 1998, 39, 2273-2276.

25 Y. Arroyo-Gomez, J. F. Rodriguez-Amo, M. Santos-Garcia and M. A. Sanz-Tejedor, Tetrahedron: Asymmetry, 2000, 11, 789-796.

26 For use of the modified Pummerer reaction in the synthesis of bicylic endoperoxide aldehydes see: M. D. Bachi, E. E. Korshin, R. Hoos and A. M. Szpilman, J. Heterocycl. Chem., 2000, 37, 639-646.

27 Y. Watanabe, K. Miura, M. Shiozaki, S. Kanai, S. Kurakata and M. Nishijima, Carbohydr. Res., 2003, 338, 47-54.

28 T. A. Johnson, D. O. Jang, B. W. Slafer, M. D. Curtis and P. Beak, J. Am. Chem. Soc., 2002, 124, 11689-11698.

29 O. Dechy-Cabaret, F. Benoit-Vical, C. Loup, A. Robert, H. Gornitzka, A. Bonhoure, H. Vial, J. F. Magnaval, J. P. Seguela and B. Meunier, Chem.-Eur. J., 2004, 10, 1625-1636.

30 O. Dechy-Cabaret, F. Benoit-Vical, A. Robert and B. Meunier, ChemBioChem, 2000, 1, 281-283.

31 Y. S. Hon and J. L. Yan, Tetrahedron, 1998, 54, 8525-8542.

32 M. V. Fernandez, P. Durantelanes and F. J. Lopezherrera, Tetrahedron, 1990, 46, 7911-7922.

33 D. Opsenica, D. E. Kyle, W. K. Milhous and B. A. Solaja, J. Serb. Chem. Soc., 2003, 68, 291-302.

34 Y. X. Dong, H. Matile, J. Chollet, R. Kaminsky, J. K. Wood and J. L. Vennerstrom, J. Med. Chem., 1999, 42, 1477-1480.

35 D. Opsenica, G. Pocsfalvi, Z. Juranic, B. Tinant, J. P. Declercq, D. E. Kyle, W. K. Milhous and B. A. Solaja, J. Med. Chem., 2000, 43, 3274 3282.

36 (a) For studies with weak base 1,2,4,5-tetraoxanes see: R. Amewu, A. V. Stachulski, S. A. Ward, N. G. Berry, P. G. Bray, J. Davies, G. Labat, L. Vivas and P. M. O'Neill, Org. Biomol. Chem., 2006, 4, 44314436.Amewu, R; (b) For studies with weak base 1,2,4-trioxolanes with excellent antimalarial activity profiles see: Y. Tang;, Y. Dong, S. Wittlin, S. A. Charman, J. Chollet, F. C. Chiu, W. N. Charman, H. Matile;, H. Urwyler;, A. Dorn; S. Bajpai;, X. Wang;, M. Padmanilayam, J. M. Karle, R. Brun and J.L. Vennerstrom, Bioorg. Med. Chem. Lett., 2007, 17, 1260-1265.

37 R. Opsenica, G. Angelovski, G. Pocsfalvi, Z. Juranic, Z. Zizak, D. Kyle, W. K. Milhous and B. A. Solaja, Bioorg. Med. Chem., 2003, 11, 2761-2768.

38 W. Trager and J. B. Jensen, Science, 1976, 193, 673-675.

39 R. K. Haynes, B. Fugmann, J. Stetter, K. Rieckmann, H. D. Heilmann, H. W. Chan, M. K. Cheung, W. L. Lam, H. N. Wong, S. L. Croft, L. Vivas, L. Rattray, L. Stewart, W. Peters, B. L. Robinson, M. D. Edstein, B. Kotecka, D. E. Kyle, B. Beckermann, M. Gerisch, M. Radtke, G. Schmuck, W. Steinke, U. Wollborn, K. Schmeer and A. Romer, Angew. Chem., Int. Ed., 2006, 45, 2082-2088.

40 W. Peters, S. L. Fleck, B. L. Robinson, L. B. Stewart and C. W. Jefford, Ann. Trop. Med. Parasitol., 2002, 96, 559-573.

41 S. N. Smilkstein, M. Kelly JX, P. Wilairat and M. Riscoe, Antimicrob. Agents Chemother., 2004, 48, 1803-1806. 